other industries involving heavy manual labour. So long as uncertainty prevails as to the true energy requirements of the individual, the assessment of the nutritional value of the family diet in the manner adopted by the Committee cannot acquire its full value. In times of financial stress the full diet of the wage-earner may have to be maintained at the expense of other members of his family, and the children may in the end be the real sufferers. It is to be hoped that the Report of the Committee is but the prelude to further investigations which will dispel the obscurity which still surrounds some of the important practical problems of human nutrition. The work is bound to be very arduous, but it is worth doing, for apart from its value to the physiologist it has a direct bearing on modern economic questions.

\section{Haddock Biology.}

M R. HAROLD THOMPSON has made a useful contribution to our knowledge of the lifehistory of the haddock in the report before us. ${ }^{1}$ This fish is of increasing commercial value, and its abundance fluctuates considerably from year to year. By the researches which Mr. Thompson describes, he certainly brings nearer the time when the causes of these fluctuations will be better understood, and he foreshadows the possibility of being able to predict for two or three years ahead any special scarcity or abundance of the fish in a particular area such as the North Sea.

Great importance has been attached to the accurate determination of the age of the fish. For the haddock it has long been recognised that the most trustworthy determinations of age can be got by studying the markings on the scales. The author has, however, subjected the whole method of age determination in this fish by means of the scales to a minute and critical examination, and especially has been at great pains to study scales taken from many different parts of the body. This careful but tedious examination has justified the methods employed, and the satisfactory conclusion has been reached, that if a few normally shaped scales be taken from a haddock, it is possible in about 95 per cent. of cases to read the age from the number of annual zones marked on them; and further, that by measuring these zones and comparing their length with the total length of the scale in each instance, one can calculate the sizes attained by the fish at the end of each previous year of its life.

The author considers that North Sea haddock grow on the average $17.5 \mathrm{~cm}$. in the first year, though the range of size is considerable, from II to $2 \mathrm{I} \mathrm{cm}$. The greatest growth in this, as in other years, takes place in the autumn, and growth practically ceases in November, when the scale has formed about 22 rings (sclerites). The first scales make their appearance when the fry are about $3 \mathrm{~cm}$. long. In 1922 and $\mathrm{r} 92 \mathrm{I}$, yearling haddock were sparsely represented in the North Sea, but the I920 brood was extremely abundant, as shown by the prolific numbers of oneyear-old fish in I92I and two-year-old fish in I922, in the later months of which year they formed the mainstay of the Aberdeen market haddock supply. The year 1904 was a similar good brood year for haddock and was followed by an abundant fishery of three-year-old fish in 1907 .

The rate of growth of the haddock varies in different regions. In the same latitude the best grown fish

1 " Fishery Board for Scotland: Scientific Investigations, 1922. No. 5 Problems in Haddock Biology, with Special Reference to the Validity and Utilisation of the Scale Theory. I: Preliminary Report." By Harold Thompson. Pp. ii $+78+3$ plates. (Edinburgh and London: H.M. Thompson. Pp. ii $78+3$ plate

$$
\text { No. } 286 \mathrm{I} \text {, vOL. I } 14]
$$

are found in shallower and warmer water, whereas there is a diminution in growth rate with increase of the depth from which they are captured. South Iceland and Faroe haddock exhibit faster growth than those captured in the North Sea and off the northern coasts of Scotland, for there favourable temperature conditions occur throughout the year, and the temperatures are so much less variable that it is often difficult to note the annual zones on the scales.

The paper is a valuable contribution to the literature of British fisheries.

\section{The Iron Ores of China.}

THE widespread distribution of local iron smelting in China led to the general belief that China possesses some of the greatest reserves of iron ore in the world. More careful investigation has failed to confirm some of the earlier estimates, and has led to the under-rating of the quantity of available Chinese iron ores. The series of Memoirs on the iron ores and iron industries of China, of which the first part by F. R. Tegengren has been issued by the Geological Survey of China, ${ }^{1}$ will correct the wild statements that have been made on both sides. The first part deals mainly with the ores of the northern and eastern provinces, and is accompanied by 16 plates and a folio atlas including 39 maps. The first map, in which the names are conveniently given both in English and Chinese, shows the general distribution of the iron ores in eastern China. It does not mark those in far western China, where there are many primitive furnaces which smelt iron for their neighbourhood. Their supplies of ore are ample, but are too remote to be of service except locally at the present time.

The Chinese iron ores are of three main types. The first type comprises the pre-Cambrian bedded ores, including the banded quartzitic ironstones that are widely spread in western Australia, India, and South Africa. Of the pre-Cambrian ores the most interesting geologically are the stromatolitic ironstones, of which one of the best known representatives are the Wabana ores of Newfoundland. The author discusses their origin and attributes them to chemical precipitation; he discourages the view of their organic origin, though on grounds which are not convincing; and he recognises that they may indicate the existence of pre-Cambrian life. The second group includes the contact ores which have been formed beside intrusive masses of granodiorite along the lower Yangtze; they include some of the most important and extensive iron ore deposits in China. The third group includes the nodular ironstones of the Palæozoic rocks and they are found especially in north central China. They have been largely mined for the local smelters, and exaggerated estimates have been often formed of their quantity. The author concludes that in most cases the nodules are in beds too thin and too scattered to be of value for working under present conditions on an extensive scale.

The text is issued in both English and Chinese. The volume and the maps are well printed and edited; misprints, such as are probably inevitable when a work by a Swedish author is issued in English and printed in China, are commendably few, though the reversal of the headings of phosphorus and silica in the table on p. 38 gives at first a startling aspect to the analyses. The subsequent parts of this important memoir will include a summary of the distribution of the iron ores of the circum-Pacific region. J. W. G.

$x$ "The Iron Ores and Iron Industry of China, including a summary of the iron situation of the Circum-Pacific Region." By F. R. Tegengren, Mem. Geol. Surv. China, Ser. A, No. 2, Pt. I., rg2r-23, 180 pp., $x 6$ pls. Accompanied by Atlas of 39 maps. Also Chinese Text. 